\title{
Pengaruh Intensitas Cahaya terhadap Pertumbuhan Tanaman Kunyit
}

\author{
Yuliyantika $^{1}$, Sudarti $^{1}$ \\ ${ }^{1}$ Program Studi Fisika Fisika, FKIP Universitas Jember, \\ Jember 68121, Indonesia \\ e-mail*:anti12432@gmail.com
}

Received: 02 Januari 2021. Accepted: 30 Januari 2021. Published: Februari 2021

\begin{abstract}
Abstrak
Salah satu tanaman yang membutuhkan intensitas cahaya adalah tanaman kunyit. Intensitas cahaya sangat mempengaruhi pertumbuhan tanaman. Tanaman membutuhkan intensitas cahaya tertentu untuk pertumbuhannya, seperti untuk lebih tinggi dan lebih rendah dengan intensitas cahaya yang normal. Tulisan ini bertujuan untuk mereview penelitian tentang faktor pertumbuhan tanaman kunyit yang terpapar langsung dengan cahaya. Metode yang digunakan dari beberapa penelitian. Selain itu faktor fisik pada intensitas cahaya juga mempengaruhi produksi metabolit. Intensitas cahaya juga dapat merangsang metabolit sekunder yang meliputi produksi gingerol dan zingiberene pada kultur Z.OfficinLe, selain itu terdapat faktor yang dapat memengaruhi pertumbuhan tanaman kunyit.
\end{abstract}

Kata kunci: intensitas cahaya, tanaman, kunyit

\section{Effect of Light Intensity on Turmeric Plant Growth}

\begin{abstract}
One of the plants that require light intensity is the turmeric plant. Light intensity greatly affects plant growth. Plants need a certain light intensity for their growth, such as to be higher and lower with normal light intensity. This paper aims to review research on growth factors of turmeric plants exposed to direct light. The method used from several studies. In addition, physical factors on light intensity also affect the production of metabolites. The intensity of light can also stimulate secondary metabolites which include the production of gingerol and zingiberene in Z.OfficinLe culture, in addition there are factors that can affect the growth of turmeric plants.
\end{abstract}

Keywords: light intensity, plants, turmeric

\section{PENDAHULUAN}

Kunyit lebih dikenal sebagai penyedap rasa pada nasi kunyit. Kunyit secara luas juga bermanfaat sebagai industri makanan, minuman obatobatan, tekstil dan kosmetik. Kunyit dapat tumbuh dengan baik dibawah naungan / tegakan hutan dengan kisaran intensitas cahaya mencapai $70 \%$. Naungan tersebut 30\% cukup untuk pertumbuhan tanaman, karena kunyit mengandung rimpang $28 \%$ glukosa, fruktosa $12 \%$ serta protein $8 \%$. Kandungan kalium pada rimpang kunyit cukup tinggi. Selain itu terdapat minyak atsiri $1,3-5,5 \%$ yang terdiri $60 \%$ keton seskiterpen, $25 \%$ zingiberina dan $25 \%$ kurkumin beserta dengan turunannya (Budiyanto, 2018)

Penelitian yang dilakukan oleh Rumiarsa melaporkan bahwa kunyit yang mengandung asam mempunyai sinergisme antiosidan yang cukup kuat yang berfungsi untuk menangkap 
oksigen singlet, oleh karena itu kunyit memiliki senyawa bioaktif yang mudah dioksidasi oleh oksigen singlet. Selain itu antioksidan berfungsi untuk memengaruhi intensitas cahaya terhadap fotooksidasi minyak kedelai yang mengandung ekstrak kunyit asam.

Intensitas cahaya yang penuh atau sedang dapat memengaruhi pertumbuhan tanaman kunyit yaitu dapat tumbuh dengan baik. sebaiknya tanaman ini di tanam pada tempat yang terbuka dengan sedikit naungan. Selain itu tanaman ini tidak tahan jika ditanam dengan air yang berlebihan, karena dapat menyebabkan kebusukan pada rimpang dan tanaman kunyit akan layu. Selain itu terdapat beberapa faktor yang dapat memengaruhi pertumbuhan tanaman yaitu intensitas cahaya dan air yang sangat berperan penting dalam pertumbuhan tanaman (Ratri, 2015).

Penelitian ini bertujuan untuk meriview penelitian tentang pertumbuhan tanaman kunyit yang terpapar oleh intensitas cahaya secara langsung. Hasil dari review tersebut dapat memberikan bahwa intensitas cahaya matahari sangat diperlukan untuk pertumbuhan tanaman kunyit.

\section{PERTUMBUHAN KUNYIT}

TANAMAN

Lingkungan sekitar juga berpengaruh dalam pertumbuhan tanaman, salah satu faktor yang dapat memengaruhi pertumbuhan tanaman yaitu intensitas cahaya, karena tidak semua tanaman memerlukan intensitas cahaya yang sama pada saat proses fotosintesis (Yustiningsih, 2019). Penelitian ekstensif yang telah dilakukan dengan pengaruh intensitas cahaya yang berbeda pada tanaman yang fotosintesis dan morfologinya seperti anatomis parameter fisiologis dan biokimia. Tanaman tersebut membutuhkan intensitas cahaya yang berbeda dengan pertumbuhan tanaman misalnya dengan lebih tinggi, atau lebih rendah dengan intensitas cahaya yang normal yang dapat menghambat fotosintesis. Untuk tanaman tumpangsari biasanya memiliki intensitas cahaya lebih rendah atau dengan kondisi cahaya yang redup (Shafiq et al 2021).

Penelitian yang dilakukan pada tanaman kunyit dipengaruhui oleh tinggi tanaman dan indeks luas daun. Pada tinggi tanaman terjadi interaksi antar cahaya dan dosis pemupukan dengan respon tinggi pada tanaman kunyit yang berumur 12 minggu / 3 bulan. Pada saat cahaya penuh maka tinggi tanaman kunyit tertinggi pada pemupukan NPK 15-15-15 dengan dosis $100 \mathrm{~kg}$ ha-1, sedangkan kunyit yang berada di bawah pohon kanopi sutera yang tidak dipangkas, dengan tinggi tanaman $145,3 \mathrm{~cm}$ dengan dipupuk $150 \mathrm{~kg}$ ha-1, tumbuhan tersebut mengandung auksin yang berfungsi mendorong pembesaran dan pemanjangan sel. Auksin lebih aktif, karena ketika intensitas cahaya rendah maka tanaman lebih tinggi sedangkan ketika intensitas cahaya tinggi maka suhu menjadi tinggi sehingga akan terjadi peningkatan aktivitas mikroorganisme tanah. Tinggi pada tanaman berkaitan dengan jumlah daun saat tumbuh dan simpul batang. Batang tersebut akan menjadi lebar karena tanaman dietiolasikan (Purnomo et al, 2018).

Daun yang lebih tebal akan memaksimalkan penterasi cahaya yang akan masuk ke dalam daun untuk memingkatkan penyerapan cahaya dengan krolopas di bawah kondisi cahaya terbatas, sedangkan daun yang lebih tipis mempunyai jaringan palisade sedikit atau krolopasnya lebih sedikit maka struktur tyersebut tidak 
mendukung pengangkutan dan pembubaran dari $\mathrm{CO}_{2}$. Oleh karena itu daun yang lebih tipis tidak mendukung dalam melakukan fotosintesis dan biomassa akumulasi. Selain itu kualitas cahaya juga memengaruhi pertumbuham dan perkembangan dari palisade daun / parenkim spons dengan ketebalan daun tersebut (Shafiq et all 2021). Tanaman juga akan mengalami peningkatan tinggi batang, panjang tangkai daun dan diameter batang menurun karena lebih banyak untuk pemanjangan batang dan tangkai daun untuk perkembangan daun dan akar. Batang akan kuat bergantung pada isisnya seperti lignin, selulosa, semi serat, sukrosa, pektin dan pati (Shafiq et al 2021).

Kunyit mengalami fotosintesis saat cahaya penuh, karena kunyit merupakan tanaman C3, apabila cahaya penuh maka dapat menurunkan laju fotosintesis (Purnomo, 2018). Penelitian tersebut bertujuan untuk mengetahui peningkatan cahaya keluar dari tanjuk pohon ketika dipangkas oleh sepertiga dari tanjuk bawah, yaitu pada pertumbuhan kunyit dalam kondisi cahaya dan kebutuhan nutrisi pada kunyit, terutama nitrogen.

Menurut penelitian Anindita et al (2015) bahwa pertumbuhan tanaman pada tanaman kunyit di bagi kedalam 4 fase yaitu pertumbuhan pada fase vegetatif sedang, pertumbuhan fase vegetatif aktif, pertumbuhan fase vegetatif lambat, dan mendekatif fase penuaan. (Gambar 2). Hasil penelitian lainnya menunjukan bahwa intensitas cahaya pada pertumbuhan kunyit dengan naungan tidak terlalu tinggi, oleh karena itu laju transpirasi yang rendah sehingga air yang berada di sekitar tanaman dapat digunakan sebagai fotosintesis. Untuk hasil daun menunjukan bahwa daun dipengaruhi oleh jumlah anakan, jadi semakain banyak jumlah anakan maka jumlah daun akan semakin banyak. Jumlah anakan terbanyak pada naungan $25 \%$ dari hasil penelitian. Sedangkan untuk akar menunjukan bahwa akar terpanjang ditunjukan pada naungan $25 \%$ yaitu $54,35 \mathrm{~cm}$ menunjukan bahwa semakin rendah nanungan maka semakin tinggi intensitas cahaya sehingga air yang di dalam tanah akan sedikit sehingga menyebabkan akar cenderung untuk memanjang untuk mencari air ke arah lapisan tanah yang lebih dalam.

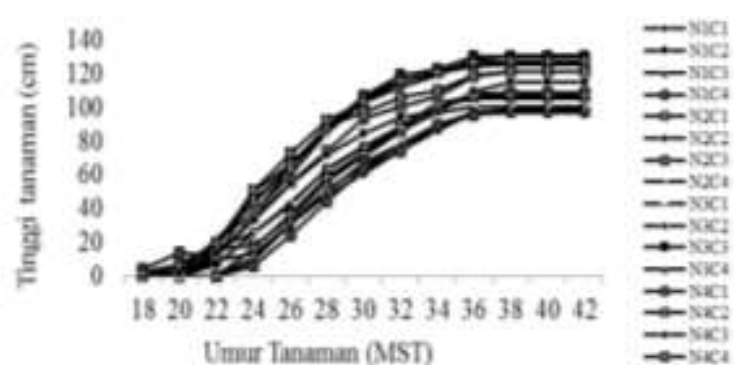

Gambar 2. Rerata Laju Pertumbungan Tinggi Tanaman Kunyit Selama 42 MST (Sumber: Ratri et all 2015)

Pada Gambar 2 tersebut menunjukan bahwa ketika tanaman berumur 18 MST-22 MST termasuk pada pertumbuhan fase vegetatif, 22 MST-32 MST termasuk pada pertumbuhan vegetatif aktif, 31 MST37 MST termasuk pada pertumbuhan vegetatif lambat, MST-42 MST termasuk pada tahap mendekati penuaan.

\section{FAKTOR YANG BERPENGARUH PADA TANAMAN KUNYIT}

Cahaya dan air merupakan dua faktor yang berperan penting dalam proses perkembangan genetika dan proses kecepatan tumbuh dengan mengasimilasi makanan untuk diubah menjadi energi. Dalam penelitian Anindita et al (2015). Hasil 
penelitiannya menunjukkan komponen pertumbuhan tanaman terdiri dari tinggi tanaman, jumlah anakan, jumlah daun, panjang akar yang menunjukan bahwa perlindungan tanaman berpengaruh nyata. Air yang berlebihan tidak berpengaruh pada semua variabel pengamat. Sedangkan berat tanaman segar menunjukan bahwa perlindungan pada tanaman dan air yang berlebihan tidak berpengaruh nyata terdapat berat tanaman. Adapun intensitas cahaya tidak berpengaruh nyata terhadap berat segar tanaman jahe. Penelitian yang dilakukan Aldi Oktavian et al (2020) bahwa kunyit mempunyai mempunyai beberapa kandungan senyawa bioaktif yang penting pada kunyit. Selain itu beberapa penelitian telah membuktikan bahwa kunyit mempunyai berbagai aktivitas farmakologis yang terdapat pada kunyit. menyebabkan pemecahan dinding dan membran sel yang menyebabkan kerusakan pada banyak sel sehingga mempermudah bahan naik ke permukaan sehingga pelarut dengan mudah menarik senyawa dari bahan. Selain itu waktu ekstraksi juga mempengaruhi ukuran partikel terhadap rendeman ekstrak VCO.

Selain itu faktor yang dapat mempengaruhi pertumbuhan tanaman kunyit yaitu menggunakan anak rimpang yang dipanen dan terkena cahaya LED selama penyimpanan jangka pendek. Hasil penelitian tersebut menunjukan bahwa kunyit mengakumulasi cadangan rimpang dengan indikator untuk kelangsungan hidup pada musim dingin dan penting untuk pertumbuhan musim berikutnya (Wangchuk et al 2019).

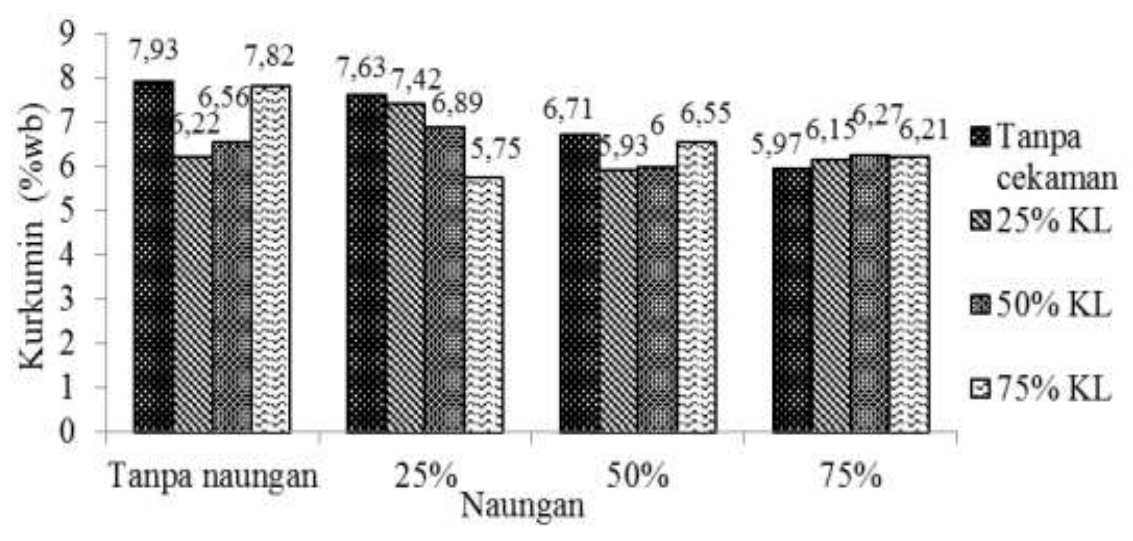

Gambar 3. Hasil Analisis Kurkumin pada Kunyit

(Sumber: Ratri et al 2015)

Metode yang digunakan merupakan metode maserasi yang digunakan untuk proses ekstraksi yang berfungsi sebagai perendam sampel dengan menggunakan pelarut organik pada suhu ruang. Faktor yang dapat mempengaruhi hasil tersebut ukuran partikel, dengan menggunakan bahan pelarut alami yaitu Virgin Coconut Oil (VCO). Hasil penelitian tersebut menunjukan bahwa semakin kecil ukuran partikel maka dapat
Untuk kombinasi LED merah dan biru dengan intensitas cahaya yang bervariasi dan panjang gelombang yang dianggap sebagai sumber efektif untuk fotosintesis (Shafiq et al 2021). Lampu merah berfungsi untuk meningkatkan akumulasi pati dengan berbagai spesies fotosintesis yang terhambat translokasi fotosintat keluar dari daun daun.

Penelitian Ratri et al 2015 menunjukkan bahwa pertumbuhan tanaman kunyit dari Gambar di atas menunjukan bahwa belum diketahui 
pengaruh cahaya terhadap kandungan kurkumin. Dari beberapa penelitian melaporkan bahwa cahaya merupakan faktor fisik yang dapat memengaruhi produksi metabolisme, karena cahaya tersebut dapat merangsang metabolisme yaitu sekunder yang meliputi zingiberene pada kultur kalus $Z$. Officinale serta produksi gingerol. Selain itu kekeringan juga menyebabkan stres oksidatif yang dapat meningkatkan jumlah flavonaid dan asam fenolat pada daun willow. Hasil penelitin tersebut menunjukan bahwa kurkumin tertinggi pada kondisi tanpa perlindungan tanaman dan air yang berlebihan. Karena kandungan kurkumin berinteraksi dengan cahaya maka tanaman kunyit yang tumbuh dengan cahaya penuh kandungan kurkuminnya lebih tinggi dibandingan dengan naungan. Selain itu untuk keetersediaan air yang tinggi juga dapat membantu meningkatkan enzim PAL (Phenilalanine Amonia Liase) yang berfungsi untuk pembentukan senyawa metolisme sekunder.

Menurut Shafiq et al 2021 bahwa tanaman akan mengalami peningkatan pada batang, panjang tangkai daun dan diameter daun menurun, apabila lebih banyak memiliki karbon dialokasikan untuk pemanjangan batang dan tangkai daun untuk perkembangan daun dan akar. Untuk tanaman naungan akan menghasikan batang yang lebih lemah dan ramping dan kekuatan yang lemah. Kekuatan batang juga tergantung pada isi batang tersebut. Selain itu intensitas cahaya yang rendah berfungsi sebagai faktor pembatas dalam biosintesis lignin untuk mengurangi aktivitas enzim. Selain itu intensitas cahaya yang lebih rendah akan mengubah ketebalan mekanis lapisan jaringan serta sel selubung bundel pembuluh darah untuk ketahanan rebah tanaman secara anatomis.
Hasil penelitian yang dilakukan oleh Rumiarsa (2018) menunjukan bahwa semakin tinggi intensitas cahaya maka oksidasi minyak kedelai yang mengandung asam lemak tak jenuh semakin cepat.hal tersebut disebabkan karena semakin meningkat bilangan peroksida, maka semakin tinggi intensitas cahaya sehingga oksidasi pada minyak kedelai yang mengandung asam lemak tak jenuh akan semakin meningkat, karena eritrosin berfungsi menyerap energi cahaya dan menstranfer energinya ke oksigen.

\section{KESIMPULAN}

Pertumbuhan tanaman kunyit dipengaruhi oleh intensitas cahaya yang penuh. Selain itu lingkungan sekitar juga berpengaruh, karena ketika tanaman kunyit kekurangan intensitas cahaya maka untuk lebih tinggi tanaman tersebut akan sulit biasanya daun akan menguning jika kekurangan intensitas cahaya, tetapi tanaman kunyit terlalu banyak cekaman air akan menyebabkan kebusukan. Tanaman kunyit akan tumbuh dengan baik tanpa naungan.

\section{DAFTAR PUSTAKA}

Meilawati, N. L. W., Melati, N. F. N., \& Rusmin, D. (2019). Effect of Rhizome Type to Viability, Growth, and Productivity of Three Turmeric Varieties. Buletin Penelitian Tanaman Rempah dan Obat, 29(2), 101-109.

Oktavian, A., Suhendra, L., \& Wartini, N. M. Pengaruh Ukuran Partikel dan Waktu Maserasi terhadap Ekstrak Virgin Coconut Oil (VCO) Kunyit (Curcuma longa L.) sebagai Pewarna Alami. JURNAL REKAYASA 
DAN MANAJEMEN

AGROINDUSTRI, 8(4), 524-534.

Purnomo, D., Budiastuti, M. S., Sakya, A. T., \& Cholid, M. I. (2018, March). The potential of turmeric (Curcuma xanthorrhiza) in agroforestry system based on silk tree (Albizia chinensis). In IOP Conference Series: Earth and Environmental Science (Vol. 142, No. 1, p. 012034). IOP Publishing.

Ratri, A.D.Y.S., Pujiasmanto, B., \& Yunus, A. (2015). Efek naungan dan cekaman air terhadap pertumbuhan dan hasil kunyit Di Kismantoro, Wonogiri. Caraka Tani: Journal of Sustainable Agriculture, 30(1), 1-6.

Rumiarsa, K., Suhendra, L., \& Suwariani, N. P. (2018). Peranan Kunyit Asam Sebagai Antioksidan Pada Fotooksidasi Minyak Kedelai. Jurnal Rekayasa dan Manajemen Agroindustri, 6(3), 225-233.

Shafiq, I., Hussain, S., Raza, M. A., Iqbal, N., ASGHAR, M. A., Ali, R. A. Z. A., \& Feng, Y. A. N. G. (2021). Crop photosynthetic response to light quality and light intensity. Journal of Integrative Agriculture, 20(1), 4-23.

Wangchuk, K., Manochai, B., Chulaka, P., Wongchaochant, S., Chintakovid, W., \& Pumprasert, J. (2018, August). Monitoring of active constituents of turmeric (Curcuma longa L.) rhizome stored under supplemented white LED-light with different light intensities. International Forum on Horticultural Product Quality 1245 (pp. 131-138).
Yustiningsih, M. (2019). Intensitas Cahaya dan Efisiensi Fotosintesis pada Tanaman Naungan dan Tanaman Terpapar Cahaya Langsung. BIO-EDU: Jurnal Pendidikan Biologi, 4(2), 44-49. 